Discussion Paper No. 11-001

\title{
Gregariousness, Interactive Jobs and Wages
}

Friedhelm Pfeiffer and Nico Johannes Schulz

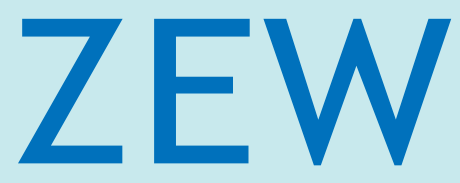

Zentrum für Europäische Wirtschaftsforschung $\mathrm{GmbH}$

Centre for European

Economic Research 
Discussion Paper No. 11-001

\title{
Gregariousness, Interactive Jobs and Wages
}

\author{
Friedhelm Pfeiffer and Nico Johannes Schulz
}

Download this ZEW Discussion Paper from our ftp server:

ftp://ftp.zew.de/pub/zew-docs/dp/dp11001.pdf

Die Discussion Papers dienen einer möglichst schnellen Verbreitung von neueren Forschungsarbeiten des ZEW. Die Beiträge liegen in alleiniger Verantwortung der Autoren und stellen nicht notwendigerweise die Meinung des ZEW dar.

Discussion Papers are intended to make results of ZEW research promptly available to other economists in order to encourage discussion and suggestions for revisions. The authors are solely responsible for the contents which do not necessarily represent the opinion of the ZEW. 


\section{Das Wichtigste in Kürze}

Geselligkeit ist eine wichtige Dimension menschlichen Daseins, deren Konsequenzen für die Verteilung der beruflichen Tätigkeiten und der Löhne noch kaum empirisch erforscht worden ist. In dieser Studie werden daher, unseres Wissens erstmals für Deutschland, die Bedeutung von Geselligkeit für die Wahl der beruflichen Tätigkeit und für damit einhergehende Lohndifferentiale untersucht. Die empirische Analyse beruht auf Stichproben aus dem Sozio-oekonomischen Panel (SOEP). Es wird gezeigt, dass etwa 80 Prozent der Beschäftigten in der Stichprobe als gesellig gelten können. Jedoch sind nur etwa 59 Prozent der Frauen und 30 Prozent der Männer in Berufen mit hoher sozialer Interaktion, in der Geselligkeit im Beruf eine bedeutende Rolle spielt, tätig. Für diese Diskrepanz gibt es zwei mögliche Ursachen. Entweder werden von den Unternehmen nicht mehr Tätigkeiten mit sozialer Interaktion angeboten, oder die Beschäftigten sind nur in begrenztem Umfang bereit, Tätigkeiten mit sozialer Interaktion auszuführen, beispielsweise, weil die Löhne für andere Tätigkeiten höher sind.

Die weiteren Ergebnisse der Studie verdeutlichen, dass die Persönlichkeitsfaktoren Extrovertiertheit und Verträglichkeit die Wahrscheinlichkeit erhöhen, in einem Beruf mit sozialer Interaktion tätig zu sein. Eine ergänzende Untersuchung mit Stichproben von Jugendlichen, die noch nicht erwerbstätig sind, bestätigt, dass diese beiden Persönlichkeitsfaktoren bereits im Jugendalter mit dem Wunsch nach sozialer Interaktion im späteren Berufsleben einhergehen. Ferner zeigen unsere Analysen, dass Frauen deutlich häufiger als Männer eine berufliche Tätigkeit mit sozialer Interaktion ausüben. Regressionsergebnisse deuten darauf hin, dass eine Tätigkeit in einem beruflichen Umfeld mit einem hohen Maß an sozialer Interaktion mit einem Lohnabschlag von 7 Prozent bei Frauen, jedoch nicht bei Männern, einhergeht. Diese Resultate haben Konsequenzen für die Lohnpolitik. Falls die gemessenen Lohndifferentiale für Frauen angeglichen würden, könnte die Beschäftigung von Frauen in Berufen mit mehr sozialer Interaktion sinken. Bei einer Lohnelastizität von 0,3 würde ceteris paribus die Beschäftigung von Frauen in Berufen mit sozialer Interaktion um 2,1 Prozent zurückgehen.

Die Studie thematisiert erstmals für Deutschland den Zusammenhang zwischen Geselligkeit, beruflicher Tätigkeit und Löhnen. Weitere Forschungen sind nun notwendig, um zu verstehen, warum Frauen häufiger als Männer eine Berufstätigkeit mit mehr sozialer Interaktion ausführen, obwohl dies mit einem Lohnabschlag verbunden ist. Unsere Ergebnisse mit den Jugendlichen zeigen, das Extrovertiertheit und Verträglichkeit bereits im Alter von siebzehn Jahren bei Mädchen stärker als bei Jungen ausgeprägt sind. Das deutet auf eine Rolle der Sozialisation in der Jugend für den Wunsch nach sozialer Interaktion hin, deren Konsequenzen für Arbeitsmarktergebnisse noch untererforscht sind. 


\section{Nontechnical Summary}

Gregariousness is an important aspect of human life with significant implications for labour market outcomes. However, there is still a research gap on the relationship between gregariousness, interactive jobs and wages. This paper therefore investigates the importance of preferences towards gregariousness for social interaction a job can be attributed to and also tries to shed a first light on the extent of equalizing wage differences in Germany. The empirical findings with samples from the German Socio-Economic Panel (SOEP) suggest that the supply of gregarious workers is higher than the amount of gregarious jobs offered in the labour market. There are two potential reasons for this finding. Either the firms do not supply more interactive jobs, or workers are not prepared to work in the jobs supplied, for instance, because of lower wages.

The findings indicate that personality and preferences matter for sorting into jobs with social interaction at the working place. The personality factors extraversion and agreeableness significantly enhance the probability to work in an interactive job. The supplement analysis with the SOEP youth questionnaires confirm that the influence of these personality factors is already effective in adolescence. It is further shown that females more often work in interactive jobs compared to males. There is evidence that working in an interactive job is associated with a compensating negative wage differential in the samples of women of 7 percent. There is no evidence for significant wage differences in the sample of males. The findings have consequences for labour market policies. Gregariousness is widespread among workers and a significant determinant of labour supply. Compensating wage differentials, however, are found only in the sample of females. If wage differentials are neutralized in interactive jobs, labour demand may decline. Given a reasonable value for the wage elasticity of 0.3 a wage increase by seven percent may reduce female employment in interactive jobs by 2.1 percent. These policy conclusions are preliminary in nature, mainly because the measured wage differential may result, alt least to some extent, also from non market clearing.

Although the study addresses a relevant and widespread dimension of human behaviour, gregariousness, and its consequences for sorting as well as its association with wages, more research is needed to understand especially the causes behind women's tastes for social interaction in the job, given the wage gap. Either these preferences are the result of socialisation in a world where adolescent women are taught to be responsible for interaction and social relationship, or it may result from comparative advantages in the division of labour during adulthood, or a combination of both. The first interpretation receives some support from the youth data, since measured personality scores differ already between girls and boys. Girls score higher in extraversion and agreeableness. 


\title{
Gregariousness, Interactive Jobs and Wages
}

\author{
Friedhelm Pfeiffer ${ }^{1}$ and Nico Johannes Schulz ${ }^{2}$
}

January 01, 2011

\begin{abstract}
:
Gregariousness is an important aspect of human life with implications for labour market outcomes. The paper examines, to the best of our knowledge for the first time for Germany, gregariousness and social interaction at the workplace and associated wage differentials. Our empirical findings with samples from the German Socio-Economic Panel (SOEP) demonstrate that gregarious people more often work in jobs with social interaction. Furthermore, females tend to work more often in interactive jobs compared to males. There is evidence that working in an interactive job is associated with a compensating negative wage differential of 7 percent for women and non for men. Implications for wage policy are discussed.
\end{abstract}

Keywords: Gregariousness, social interactions, labour markets, sorting, wage differentials.

JEL classification: J01, J24, J31

Acknowledgements: We would like to thank the Leibniz Association for supporting this study in the research network "Noncognitive Skills: Acquisition and Economic Consequences". We thank Melanie Arntz, Bodo Aretz, Andrea Mühlenweg, Johannes Gernandt and Julia Schäfer for helping us classifying interactive jobs and Daniel Erdsiek for competent research assistance. We thank Christiane Bradler, Wolfgang Franz and Bas van der Klaauw for helpful comments on an earlier version of the paper. Any remaining errors are our own.

Corresponding author: Friedhelm Pfeiffer, Centre for European Economic Research (ZEW), P.O. Box 103443, 68034 Mannheim, Germany, Tel.: +49-6211235-150, E-mail: pfeiffer@zew.de.

${ }^{1}$ Centre for European Economic Research, ZEW Mannheim

${ }^{2}$ Alumnus, University of Mannheim 
"The human being is in the most literal sense [...] not merely a gregarious animal, but an animal which can individuate itself only in the midst of society.” Karl Marx (1857) ${ }^{1}$

\section{Introduction}

As the quotation from Karl Marx suggests, gregariousness is an important aspect of human life which should also have significant implications for the distribution of jobs and wages. However, there is still a research gap on the relationship between gregariousness and labour market outcomes. ${ }^{2}$ The study by Krueger and Schkade (2008) indicates that gregarious workers sort themselves into jobs that entail more social interaction. To the best of our knowledge there is no evidence on sorting by males (Krueger and Schkade, 2008, investigated sorting for females) and on wages. In our paper implication of gregariousness for sorting into interactive jobs and related wage differences are examined for male and female workers, to the best of our knowledge for the first time with German data.

Krueger and Schkade (2008) explore the drivers for sorting into interactive jobs with data based on the day reconstruction method. Since the authors do not have direct information on the personal taste for gregariousness in their samples of females, they interpret social interactivity during leisure time as a proxy for gregariousness preferences also while working. They find that female workers who are more gregarious in their leisure time also inhibit a higher probability to be employed in a job with more social interaction. Furthermore, they demonstrate that females working in interactive jobs are on average more satisfied with their jobs compared with workers in jobs with less social interaction.

Our contribution to this literature on gregariousness and labour market outcomes utilizes data from the German Socio-Economic Panel (SOEP). The richness of socio-economic information, psychometric measures on individual tastes and personality as well as the occupation chosen gives us the opportunity to focus on the determinants of sorting and on equalizing wage differentials from working in a job with more or less social interaction. Individual tastes for gregariousness are taken from the personality factors extraversion and agreeableness. In the spirit of Krueger and Schkade (2008) respondents' information on the extent of social interaction in

\footnotetext{
${ }^{1}$ See Marx (1993:84). In German: „Der Mensch ist im wörtlichsten Sinn ... nicht nur ein geselliges Tier, sondern ein Tier, das nur in der Gesellschaft sich vereinzeln kann.“ (Karl Marx and Friedrich Engels, 1961, Werke Band 13, Dietz Verlag, Berlin, page 616).

2 According to the "theory of equalizing differences" (Rosen, 1986) individual tastes and preferences related to work activities create sorting in the labour market and wage differences. Workers do not only differ in their competences for the different job requirements but also in their tastes with respect to the working environment and attributes of the job. Differences in preferences for gregariousness for instance may lead individuals to sort themselves in working environments with different levels of social interaction. As a consequence, wages may differ between jobs with equal competence requirements but divergent extents of social interaction.
} 
leisure time is used in addition to assess the extent of gregariousness in the working population.

Since measured personality factors may depend - at least to some extent - on job attributes, such interdependency may create biased estimates. To investigate the direction of such a potential bias a supplemental sample of seventeen year olds is utilized. The sample is taken from the SOEP youth questionnaires. Questions deal with preferred job attributes later at work, among them the desirability of social interaction. Since the youth questionnaire contains the same psychometric measures of personality as the questionnaire for adults, the sample allows us to investigate the relevance of gregariousness without the problem of interdependency, since the seventeen year olds respondents are not working.

Our empirical findings suggest first that roughly 80 percent of the workers in our samples enjoy interaction. There is no difference between females and males. Interestingly however, at the working place only 59 percent of women and 30 percent of men are engaged in jobs with high interpersonal interaction. There are two potential reasons for this finding. Either the firms do not supply more interactive jobs, or workers are not prepared to work in the jobs supplied, for instance, because of lower wages. Second, the data indicate a significant positive relationship between the personality factors extraversion and agreeableness and the probability to work in an interactive job. The analysis with the SOEP youth questionnaire shows that these personality factors contribute to the desire for social interaction in the job already in adolescence, strengthening the results in the samples of adults. Third, regression analyses indicate a negative wage differential for women of around 7 percent for working in an interactive job and no wage difference for men.

The findings have consequences for labour market policies in general and more specific for equalizing wage policies. On the one hand it has been shown that gregariousness is widespread among workers and that it is a significant determinant of labour supply and sorting into jobs. On the other hand, compensating wage differentials are found only in the sample of females. If wage policies designed to neutralize these wage differentials in interactive jobs, labour demand may decline. Given a wage elasticity in the labour market of 0.3 (Dan Hamermesh's best estimate) a wage increase by seven percent may reduce female employment in interactive jobs by 2.1 percent.

The rest of the paper is structured as following. In section 2 a theoretical model of sorting and wage differentials in an environment of heterogeneously interactive jobs and divergent tastes for social interaction at the working place is introduced, together with a review of empirical findings. In section 3 data are introduced. Section 4 discusses the econometric results on the determinants of choosing interactive jobs and section 5 on the extent of wage differences. Section 6 concludes. 


\section{Theoretical reasoning on gregariousness, interactive jobs and wages}

The introduction of the model discussed in Krueger and Schkade (2008) shall be helpful to understand the relationship between gregariousness, interactive jobs and wages. In Krueger and Schkade (2008) jobs are either interactive $(S=1)$ or noninteractive $(S=0)$. It is assumed that all workers have the same productivity but differ in their valuation of job interactivity which is modelled by $u_{i}(w, S)$ where $\mathrm{w}$ indicates wages. All workers derive a positive utility from an increase in their wage, i.e. $\partial u_{i}(w, S) / \partial w>0 \forall i$. However, their valuation of interactivity depends on the individual worker type $\left(z_{i}\right)$. Some workers like interactivity, others do not: $\partial u_{i}(w, S) / \partial S>0$ or $\partial u_{i}(w, S) / \partial S<0$. The worker type $z_{i}$ is defined by $u_{i}\left(w_{1}+z_{i}, 0\right)=u_{i}\left(w_{1}, 1\right)$ and can be interpreted as an individual compensating variation for working in a non-interactive job. Hence, $z_{i}$ is higher for more gregarious and lower for less gregarious workers.

The implications of this reasoning are the following: If the offered wage premium for working in a non-interactive job $\Delta w=w_{0}-w_{1}$ is higher than $z_{i}$, the individual sorts into a job with $S=0$. On the other hand, the individual sorts into a job with $S=1$ if $\Delta w<z_{i}$. Since $z_{i}$ is assumed to be distributed with density $g\left(z_{i}\right)$, the supply for non-interactive jobs $(S=0)$ can be derived by $\int_{0}^{\Delta w} g(z) d z=G(\Delta w)$. The supply depends on the distribution of tastes in the working population.

In this model there are only two equilibrium wages, one for interactive, one for non interactive jobs. No further wage differentials exist between individuals working in the same type of job (i.e. in $S=0$ or $S=1$ ). In social reality workers have different competences and a wealth of individual wage contracts may exist for various other reasons. Therefore, in our empirical analysis of wage differentials sex, age, years of education and personality factors are used in addition to social interactivity at jobs.

Krueger and Schkade (2008) analyze four different data sets from the U.S. (Texas, Columbus) and France (Rennes). The data inhibit detailed information ${ }^{3}$ on the time that individuals found themselves in social interactions at work and at home. On average 57 percent of the leisure-time and 72 percent (90 percent) ${ }^{4}$ of work time is spent in social interactions. The authors estimate Tobit models with the share of time

\footnotetext{
${ }^{3}$ The high degree of detail is achieved by using the Day Reconstruction Method (DRM) in which individuals are asked to segment their days into episodes and give a description on their social environment in each episode. The result is a share of total work time in which the respective individual was interacting with others at work and a share of total leisure time in which the respective individual was interacting with others in his leisure time.

${ }^{4}$ Without parentheses: time in conversations; in parentheses: time interacting with people.
} 
spent interacting at work as a dependent variable. The main focus is to find a proxy variable for $z_{i}$. The idea is to take the share of time spent interacting with others in the leisure time. Furthermore, the control variables age, household income and dummies for marriage, college degree, union membership and race are used. The results indicate a significant and relatively strong relationship between the proportion of time spent interacting in the leisure time and the proportion of time spent interacting in the work time. A 10 percentage point increase of the proportion of time spent interacting in the leisure time leads - on average - to a positive 5 percentage points change in the proportion of time spent interacting at work. This effect is robust across datasets.

Krueger and Schkade (2008) discuss two critical issues in their analysis. First, the reliability of the data may be questioned, insofar as it inhibits only DRMquestioning for a single working day. Thus results could be biased because of unusually shaped working days in combination with the relatively small sample size. Second, it is not possible to infer causal statements from the analysis as it is unclear whether the job environment affects the social behaviour in the leisure time or vice versa. As we also are not able to fully tackle this simultaneity issue in our econometric analysis with adults, we provide additional evidence for the sorting equations by utilizing data from not working juveniles on their job aspirations.

Another strand of the literature discusses the role of pro-social behaviour and preferences as an incentive to provide effort at the workplace. ${ }^{5}$ Workers with prosocial preferences may be concerned with social aspects in the organisation of working places. These workers may require less monetary compensation for doing the same job compared to a worker without pro-social behaviour. Women's effort seems to depend more on social preferences compared to men's, which is in line with our findings. Gregariousness might share similar dimensions with social preferences, although taken literally it focuses on enjoying the company of other people. It does neither imply nor exclude that people have pro-social preferences.

Our empirical study provides evidence on the distribution of gregariousness and the amount of social interaction in jobs among samples from the working population, separately for females and males. As in the theoretical model jobs are categorized as either interactive or non interactive. If supply exceeds demand for interactive jobs, some workers with a desire for social interaction may agree to be paid with lower wages if they work in an interactive job. Although the empirical research programme is close to the theoretical model we are, however, not fully able to distinguish market clearing from preferences effects. Our innovation is to examine the distribution of gregariousness and social interaction in SOEP samples from the working population and its correlation with wages.

\footnotetext{
${ }^{5}$ See Croson and Gneezy (2009), Tonin and Vlassopoulos (2009) among others.
} 


\section{Data}

\subsection{The samples selected and the construction of variables}

The empirical part is based on samples taken from the German Socio-Economic Panel (SOEP), waves 2004 to 2007. The SOEP provides representative data for the German population (see Wagner et al., 2007). We use a sample of adults who were between 18 and 65 years old in the year 2007 and employed. Furthermore, a sample of seventeen year olds is taken from the SOEP youth questionnaires 2005 to 2007. The adult sample is further defined by the availability of information for the following variables from the years 2004 to 2007:

A dummy variable indicating working in an interactive job (social interaction) created using the ISCO-88 classification, compiled in 2007. The ISCO-88 defines important job attributes and tasks for each individual job according to the standard occupational four-digit classification scheme (DIW Projectgroup, 2007: 14 ff). To classify an occupation as interactive (1) or not interactive (0), five colleagues (three women, two men) were asked to categorize the jobs' interactivity levels as either 1 ("non interactive"), 2 ("rather non interactive"), 3 ("interactive") or 4 ("very interactive") for each four-digit occupation, in addition to the joint assessment of the authors. For instance, the occupation "mechanic" was assessed to have no interactivity (1) while "nurse" was assessed to be very interactive (4) by all raters.

The average correlation among these six ratings was 0.76 . To be compatible with the theoretical model and to reduce possible errors stemming from misclassifications, the resulting four point Likert scale was aggregated to the binary dummy variable social interaction which combines assessment 1 and 2 for no or low (0) and 3 and 4 for interactivity or high interactivity (1). In Appendix 1 the shares of job with social interaction and average wages are summarized for the samples of females and males on the two digit ISCO-88 levels.

Furthermore, a dummy variable for gregariousness during leisure time has been created. This variable is obtained from respondents' assessment on the frequency of meeting with friends, relatives or neighbors during leisure time, in the year 2007. In the spirit of Kruger and Schkade (2008) it is interpreted as an indicator for individual preferences for interactivity.

Hourly wage in $2007 \quad(w)$ are calculated by the following formula: $w=y_{\text {month }} /\left(h_{\text {week }} * 4.3\right)$, where $y_{\text {month }}$ is the individual gross monthly income and $h_{\text {week }}$ is the number of working hours per week. ${ }^{6}$ The other variables used are the number of

\footnotetext{
${ }^{6}$ To eliminate implausible declarations only observations from individuals who work between 15 and 100 hours a week and have a gross monthly income of at least $250 €$ are taken. In addition, hourly wages are trimmed (Bottom/Top one percentile) to avoid biases from extreme outliers (see Gernandt and Pfeiffer, 2007, among others).
} 
years spent in education (schooling; compiled in 2007), the number of years of potential professional experience (experience $=$ age - schooling-age, compiled in 2007), and the Big Five personality factors: openness to experience, conscientiousness, extraversion, agreeableness, neuroticism (Borghans et al., 2008, Costa and McCrae, 1992; Heineck and Anger, 2010, among others) derived from data compiled in the year 2005. Furthermore, positive and negative reciprocity (Fehr and Gächter, 2000; Dohmen et al., 2009, among others), and the external locus of control (Heineck and Anger, 2010, among others), both derived from data compiled in the year 2005, and willingness to take risks (Dohmen et al., 2010, among others) compiled in the year 2004 have been constructed. Raw data on personality, preferences and noncognitive skills are aggregated with factor analysis (c.f. Costa and McCrae, 1992; Kline, 1994; Borghans et al., 2008, p.9 ff.) ${ }^{7}$ to employ comprehensive measures of personality and preferences in the regression analysis.

\subsection{Descriptive evidence}

To study sorting, we focus on the role gender and personality contributes to sorting into interactive and non-interactive jobs. Wages are investigated among interactive and non-interactive jobs, to study its differentiation according to the type of social interaction at the working place while controlling for a wealth of human capital variables and for the taste for gregariousness.

Table 1 gives a gender specific overview on all manifestations of the utilized variables, based on a total sample size of $n=3,985$ males and $n=3,315$ females $^{8}$. About 83 percent of women and 80 percent of men in our samples of the German working population respond to be socially interactive in their leisure time (meet with friends or relatives). If responding in this way indicates a taste for gregariousness, these findings suggest that most German workers, more than 80 percent, can be categorized as being gregarious, confirming the introductory citation of Karl Marx. There is, if any, only a small gender difference in the population. Interestingly however, at the working place only 59 percent of women and 30 percent of men actually are engaged in jobs with high interpersonal interaction. In labour markets there seem to be less jobs available with high social interactivity compared to the

\footnotetext{
${ }^{7}$ The Principal Component Factor method was used with an oblique rotation to obtain the Big Five personality factors. Despite the fact that in the literature orthogonal rotation is widely used to obtain the Big Five factors from personality inventories (c.f. Block, 1995) oblique factor rotation was used because a highly significant correlation was observed between factors when using the oblique rotation method. Calculation of Cronbach's Alpha for external locus of control yields a value of 0.69 which is feasible, whereas the Cronbach's Alpha for internal locus of control indicates with 0.42 a relatively low reliability of the available scale. Since the factors for positive and negative reciprocity are correlated only weakly, it is feasible to use orthogonal rotation in this case. The factors for external and internal locus of control significantly correlate. Therefore oblique rotation is more feasible. However utilizing Cronbach's Alpha (c.f. Cortina, 1993) indicates that of those two only the factor for external locus of control is reliable ${ }^{7}$. Hence, we concentrate our analysis on external locus of control and do not further include the factor for internal locus of control. ${ }^{8}$ If willingness to take risk is included in the analysis this reduces the sample sizes to $n=3,821$ for men and $n=3,192$ for women.
} 
supply of workers who are gregarious. Either the firms do not supply more interactive jobs, or workers are not prepared to work in the jobs supplied, for instance, because of lower wages. There is no significant correlation between being in an interactive job and gregariousness during leisure time.

The average age in both samples is around 43 years, whereas the gross hourly wage is significantly lower for females (females: $13 € / h$ vs. men: $16.5 € / h$ ). The average number of years of education (schooling) and the average number of years of potential job experience (experience) is similar for both sexes. On average workers have invested into 13 years of education and have accumulated 24 years of potential job experience. The means for preferences and personality variables lie around zero with a standard deviation of unity, which is generally the case when factor analysis is utilized. Since factors are unit free, variables indicate individual differences in personality in a standardized way. The benchmark is the average individual in the sample. With respect to the personality factors, men and women are comparably open to experience, conscious, positive reciprocal and external regarding their locus of control. However, men are significantly less extraverted, agreeable and neurotic than women, and seem to more negative reciprocal and willing to take risks.

\section{Determinants of sorting into an interactive job}

To test the association between tastes for gregariousness (i.e. the Big Five factors extraversion and agreeableness) and being in an interactive job a logistic regression model is estimated. Utilizing pooled samples of females and males we test the significance of sex, schooling, experience, personality factors, positive and negative reciprocity, external locus of control and willingness to take risk for social interaction at the working place. The results in form of odds-ratios for two estimates, regression (1) and (2) are shown ${ }^{9}$ in Table 2. Regression (2) includes $w$ as an additional control variable while regression (1) does not. Wages are included in order to conduct a simple causality check.

From Table 2 three main results emerge. First, females have a higher probability of working in an interactive job compared to males. For women the odds for working in an interactive job are 3.5 times higher than for men. This holds when controlling for educational and professional background as well as personality and preference related variables. Second, tastes and personality matter. More extravert and agreeable workers have a significantly higher probability of working in a gregarious job. Neither neuroticism, nor reciprocity nor locus of control is related to working in a gregarious job. Surprisingly, however, conscientiousness exerts a negative

\footnotetext{
${ }^{9}$ Note that not all coefficients are documented in the table due to space restrictions. For the number of years of education the second power is included as well, and for years of potential experience the second, third and fourth power. They are available by the authors upon request.
} 
relationship with working in an interactive job and willingness to take risk a positive. A possible explanation may be that working in interactive jobs exerts somehow greater risk (for instance, a higher risk of infection during interaction) so that more risk loving workers are engaged there. Clearly, more research with different data is needed to confirm the interpretation and these results. Third, regression (2) indicates that there is no significant partial correlation between wages and social interaction. Therefore in the logistic regression simultaneity between individual wages and social interaction at the job does presumably not bias results.

Nevertheless, since personality is not measured systematically before the individuals self-sorted into their professions, these logistic estimates may not show a causal relationship. For example, workers may become more extraverted when they work in an environment with high social interactivity. In this case personality factors and social interaction at the job are interdependent and the parameters presumably are biased. In order to understand the role of personal factors for social interaction at the working place more deeply, we use supplement data with a similar set of psychometric personality measures. These data have been taken from the youth questionnaires available in the $\mathrm{SOEP}^{10}$ to estimate a model similar to the one that has been estimated for adults. In this supplement data there is a main difference. The adolescent respondents are not working and were asked instead about the importance of social interaction in a desired job as a selection criterion for their desired jobs in the future. Interdependency between personality and job attributes is not a problem here.

The variable preference for social interaction in a desired job has been measured on a four point Likert scale ( 1 = "unimportant", $2=$ "not very important", 3 = "important", 4 = "very important"). The two lower and two upper categories are aggregated to a $0 / 1$ indicator variable, similarly to the analysis of job gregariousness with the samples of adults. A logistic regression model is estimated. The right hand side variables include the same personality factors that were utilized in adults' samples.

Results are summarized in Appendix 2. In the pooled model (both males and females in one sample) an individual with a one standard deviation higher score in extraversion is about 1.9 times more likely to prefer more social interaction in a job than the average individual. In the adult sample it is lower, 1.1 (see Table 2). The odds-ratio coefficient for agreeableness is estimated at 1.5 and is therefore also higher than in the models performed with the adult sample (1.1). Another important result is that exclusively for female youths the factor external locus of control seems to be playing an important role for preferring an interactive job; for females an increase of one standard deviation in external locus of control significantly increases

\footnotetext{
${ }^{10}$ We include the waves 2005 to 2007 of the youth questionnaires in each of which the seventeen year olds answer questions on various topics including their personality and their preferences for their future employment.
} 
the odds for preferring an interactive job by the factor 1.5. For male youths immigration seems to have a weakly significant negative effect on preferring interactivity at work (Odds-Ratio coefficient: 0.53, $10 \%$ significance level).

While confirming the existence of a strong and highly significant effect of gender, the findings indicate in addition that the association between the personality factors extraversion and agreeableness for sorting into gregarious jobs is underestimated in the models with adult data. Either these preferences are the result of socialisation in a world where adolescent women are taught to be responsible for interaction and social relationship, or it may result from comparative advantages in the division of labour during adulthood, or a combination of both. The first interpretation receives some support from the youth data, since measured personality scores differ already between girls and boys. Girls score higher in extraversion and agreeableness.

\section{Social interaction and wages}

In this section the hypothesis that wage differentials are related to the job attribute social interaction is investigated based on extended versions of Mincer-type wage regressions. In the wage regressions human capital variables are controlled for, among them the education and the personality factors extraversion and agreeableness. Two regressions are performed with pooled samples (males and females) and furthermore there are two gender specific regressions. Table 3 summarizes the results of the first four equations estimated with the natural log gross hourly wage as the dependent variable and years spent in education, potential experience and potential experience squared as right hand side variables. Specification (1) contains a dummy variable indicating that there is a high degree of social interaction at the job and a female dummy. Specification (2) includes a further interaction term between social interaction and female (social interaction * female).

Results from regression (1) demonstrate a negative wage differential for working in a gregarious job of approximately 4.1 percent. However, when including the interaction between gender and social interaction (social interaction * female, specification (2)), the negative wage differential for working in an interactive job per se vanishes. For females working in a job with social interaction the coefficient now is negative (-0.061) and significant. This finding is further substantiated by the gender specific regressions (3) and (4). In the female sample (equation (4)) the coefficient is minus 0.072 (given logarithmic wages this is a mean wage difference of around 7.5 percent). The coefficient proves also to be robust in a reduced sample for individuals aged between 25 and 55 years (results are available from the authors upon request). The coefficient for women has a comparable magnitude (0.068, S.E.= $0.017)$ and again there is no significant wage penalty for men. The findings hint at 
the relevance of preferences for jobs with social interaction. Since females have stronger preferences for social interaction at the working place, supply is high and negative wage differences emerge.

To investigate potential wage differences according to personal traits for gregariousness in further specifications interaction terms of social interaction and the personality factors extraversion and agreeableness have been included in the log wage equations. Results from gender specific regressions are summarized in Table 4. The significance of negative compensating wage differentials remains robust when including the personality factor extraversion. Extraversion is assumed to carry a close relationship with gregariousness (see Krueger and Schkade, 2008). Extraversion has neither a significant relation with wages in general, nor a significant relation with wages in jobs with social interaction, at least in these specifications. This holds for females and males. Furthermore, and in accordance with Heineck and Anger (2010), agreeableness is related negatively with wages. However, in our study the coefficient is negative only for jobs with no (or low degrees of) social interaction. For individuals working in jobs with social interaction wages are not significantly related with agreeableness. A higher amount of agreeableness is related with lower wages only in jobs with no or low social interaction.

The analysis demonstrates that there are robust regularities in the data which highlight the role of gregariousness, or to cite again Karl Marx, "to individuate itself in the midst of society", for labour market outcomes. Sorting into jobs depends on tastes for gregariousness and negative wage differentials emerge for females in interactive jobs. These findings have consequences for wage policies. They suggest that if wages in more interactive jobs are equalized, employment of women may decline. Given a wage elasticity in the labour market of 0.3 (Dan Hamermesh's best estimate) a wage increase by seven percent reduces female employment in interactive jobs by 2.1 percent. There are, however, limitations in our analysis and these policy conclusions are preliminary in nature. First, the utilized wage regression is not fully able to separate market clearing effects in labour markets from the efficacy of preferences, although the use of psychometric measures of personality should be helpful to reduce bias. Second nonparticipants and unemployed workers may affect the results, if gregariousness among these groups is decisive for participation. Wage differentials may increase (decrease) if they are more (less) gregarious on average.

\section{Conclusion}

Gregariousness is an important aspect of human life with significant implications for labour market outcomes. However, there is still a research gap on the relationship 
between gregariousness, interactive jobs and wages. This paper therefore investigates the importance of preferences towards gregariousness for social interaction a job can be attributed to and also tries to shed a first light on the extent of equalizing wage differences in Germany. The empirical findings with samples from the German Socio-Economic Panel (SOEP) suggest that the supply of gregarious workers is higher than the amount of gregarious jobs offered in the labour market. There are two potential reasons for this finding. Either the firms do not supply more interactive jobs, or workers are not prepared to work in the jobs supplied, for instance, because of lower wages.

The findings indicate that personality and preferences matter for sorting into jobs with social interaction at the working place. The personality factors extraversion and agreeableness significantly enhance the probability to work in an interactive job. The supplement analysis with the SOEP youth questionnaires confirm that the influence of these personality factors is already effective in adolescence. It is further shown that females more often work in interactive jobs compared to males. There is evidence that working in an interactive job is associated with a compensating negative wage differential in the samples of women of 7 percent. There is no evidence for significant wage differences in the sample of males.

The findings have consequences for labour market policies. Gregariousness is widespread among workers and a significant determinant of labour supply. Compensating wage differentials, however, are found only in the sample of females. If wage differentials are neutralized in interactive jobs, labour demand may decline. Given a reasonable value for the wage elasticity of 0.3 a wage increase by seven percent may reduce female employment in interactive jobs by 2.1 percent. These policy conclusions are preliminary in nature, mainly because the measured wage differential may result, alt least to some extent, also from non market clearing.

Although the study addresses a relevant and widespread dimension of human behaviour, gregariousness, and its consequences for sorting and its association with wages, more research is needed to understand the causes behind women's tastes for social interaction in the job. Either these preferences are the result of socialisation in a world where adolescent women are taught to be responsible for interaction and social relationship, or it may result from comparative advantages in the division of labour during adulthood, or a combination of both. The first interpretation receives some support from the youth data, since measured personality scores differ already between girls and boys. Girls score higher in extraversion and agreeableness. Improvements in the database should be fruitful. In future work, one should combine psychometric personality data with the data reconstruction method to collect more detailed information on the amount of social interaction at the workplace. 


\section{References}

Block, J. (1995), A contrarian view of the five-factor approach to personality description. Psychological Bulletin, 117, 187-215.

Borghans, L., Duckworth, A., Heckman, J. J. and B. Weel (2008), The Economics and Psychology of Personality Traits. Journal of Human Resources, 43 (4), 9721059.

Cortina, J. M. (1993), What is coefficient alpha? An examination of theory and applications. Journal of Applied Psychology, 78, 98-104.

Costa, P. T. and R. R. McCrae (1992), Normal personality assessment in clinical practice: The NEO Personality Inventory. Psychological Assessment, 4, 5-13.

Croson, R. and Z. Gneezy (2009), Gender Differences in Preferences, Journal of Economic Literature, 47 (2), 448-474.

Dohmen, T., Falk, A., Huffman, D. and U. Sunde (2009), Homo reciprocans: survey evidence on behavioral outcomes. Economic Journal, 119 (536), 592-612.

Dohmen, T., Falk, A., Huffmann, D. and U. Sunde (2010), Are Risk Aversion and Impatience Related to Cognitive Ability? American Economic Review, 100 (3), 1238-1260.

DIW Projectgroup (2007), Documentation PGEN: Person related status and generated variables. Berlin.

Fehr, E. and S. Gächter (2000), Cooperation and Punishment in Public Goods Experiments. American Economic Review, 90, 980-994.

Gerlitz, J. and J. Schupp (2005), Zur Erhebung der Big-Five-basierten Persönlichkeitsmerkmale im SOEP. DIW Research Note, 4, Berlin.

Gernandt, J. and F. Pfeiffer (2007), Rising Wage Inequality in Germany. Journal of Economics and Statistics, 227 (4), 358 - 380.

Heineck, G. and S. Anger (2010), The returns to cognitive abilities and personality traits in Germany. Labour Economics, 17 (3), 535-546.

Kline, P. (1994), An Easy Guide to Factor Analysis. Routledge, New York.

Krueger, D. and A. B. Schkade (2008), Sorting in the Labor Market: Do Gregarious Workers Flock to Interactive Jobs? Journal of Human Resources, 43 (4), 859-883.

Marx, K. (1993), Grundrisse der Kritik der Politischen Ökonomie (Rohentwurf). Reprint Penguin Books: London (the original was written by Karl Marx in the years 1857 and 1858 in London, first published in 1939, translation from 1973). 
Rosen, S. (1986), The theory of equalizing differentials. In: O. Ashenfelter and R. Layard (eds.), Handbook of Labor Economics Vol. 1, Amsterdam, North Holland, 641-692.

Tonin, M. and M. Vlassopoulos (2009), Disentangling the Sources of Pro-Social Behaviour in the Workplace: A Field Experiment, Discussion Paper Series in Economics and Econometrics 0901, University if Southampton.

Wagner, G. G., J. R. Frick and J. Schupp (2007), The German Socio-Economic Panel Study (SOEP) -Scope, Evaluation and Enhancements. Schmollers Jahrbuch - Journal of Applied Social Science Studies, 127(1), 139-169. 
Table 1: Descriptive statistics

\begin{tabular}{|c|c|c|c|c|}
\hline \multirow[b]{2}{*}{ Variables } & \multicolumn{2}{|c|}{ males } & \multicolumn{2}{|c|}{ females } \\
\hline & mean & std.-dev. & mean & std.-dev. \\
\hline social interaction & 0.30 & 0.46 & 0.59 & 0.49 \\
\hline $\begin{array}{l}\text { gregariousness } \\
\text { in leisure time }\end{array}$ & 0.80 & 0.40 & 0.83 & 0.37 \\
\hline age & 43.26 & 10.79 & 42.56 & 10.59 \\
\hline$w$ & 16.49 & 8.22 & 13.02 & 6.47 \\
\hline$y_{\text {month }}$ & 3,202.96 & $1,792.18$ & $2,001.70$ & $1,248.88$ \\
\hline$h_{\text {week }}$ & 193.40 & 38.24 & 152.05 & 46.73 \\
\hline schooling & 12.74 & 2.79 & 12.87 & 2.70 \\
\hline potexperience & 24.52 & 10.77 & 23.69 & 10.91 \\
\hline open to experience & 0.00 & 0.92 & 0.11 & 0.93 \\
\hline conscientiousness & 0.05 & 0.91 & 0.15 & 0.87 \\
\hline extraversion & -0.05 & 0.97 & 0.18 & 0.98 \\
\hline agreeableness & -0.25 & 0.98 & 0.14 & 0.91 \\
\hline neuroticism & -0.28 & 0.94 & 0.12 & 0.97 \\
\hline positive reciprocity & 0.01 & 0.95 & 0.02 & 0.96 \\
\hline negative reciprocity & 0.14 & 0.98 & -0.11 & 0.94 \\
\hline locus of control & -0.17 & 0.95 & -0.10 & 0.95 \\
\hline $\begin{array}{l}\text { willingness to take } \\
\text { risk }\end{array}$ & 5.22 & 2.11 & 4.45 & 2.11 \\
\hline
\end{tabular}

Source: Sample taken from SOEP 2007 (see text); 3,985 male and 3,315 female observations (exception: 3,821 male and 3,192 female observations for the variable willingness to take risk). 
Table 2: Odds-Ratios from logistic regression models for social interaction at the job

\begin{tabular}{|c|c|c|}
\hline & (1) pooled & (2) pooled \\
\hline \multirow[t]{2}{*}{$\operatorname{sex}$} & $3.490 * * *$ & $3.438 * * *$ \\
\hline & $(0.195)$ & $(0.196)$ \\
\hline \multirow[t]{2}{*}{ schooling } & 0.905 & 0.904 \\
\hline & $(0.092)$ & $(0.092)$ \\
\hline \multirow[t]{2}{*}{ potexperience } & $1.139 * *$ & $1.145^{* *}$ \\
\hline & $(0.072)$ & $(0.072)$ \\
\hline \multirow[t]{2}{*}{ openness to experience } & $1.078^{* *}$ & $1.079 * *$ \\
\hline & $(0.033)$ & $(0.034)$ \\
\hline \multirow[t]{2}{*}{ conscientiousness } & $0.923 * *$ & $0.921 * *$ \\
\hline & $(0.030)$ & $(0.030)$ \\
\hline \multirow{2}{*}{ extraversion } & $1.122 * * *$ & $1.122 * * *$ \\
\hline & $(0.032)$ & $(0.032)$ \\
\hline \multirow[t]{2}{*}{ agreeableness } & $1.108 * * *$ & $1.105^{* * *}$ \\
\hline & $(0.035)$ & $(0.035)$ \\
\hline \multirow[t]{2}{*}{ neuroticism } & 0.993 & 0.991 \\
\hline & $(0.029)$ & $(0.029)$ \\
\hline \multirow[t]{2}{*}{ positive reciprocity } & 0.993 & 0.993 \\
\hline & $(0.029)$ & $(0.029)$ \\
\hline \multirow[t]{2}{*}{ negative reciprocity } & 1017 & 1017 \\
\hline & $(0.031)$ & $(0.031)$ \\
\hline \multirow[t]{2}{*}{ locus of control } & 0.976 & 0.971 \\
\hline & $(0.030)$ & $(0.030)$ \\
\hline \multirow[t]{2}{*}{ willingness to take risks } & $1.040 * * *$ & $1.040 * * *$ \\
\hline & $(0.013)$ & $(0.013)$ \\
\hline \multirow[t]{2}{*}{ wages } & & 0.995 \\
\hline & & $(0.004)$ \\
\hline \multirow[t]{2}{*}{ constant } & $0.158 * *$ & $0.157^{* *}$ \\
\hline & $(0.116)$ & $(0.115)$ \\
\hline pseudo $\mathrm{R}^{2}$ & 0.092 & 0.092 \\
\hline $\mathrm{N}$ & 7,013 & 7,013 \\
\hline
\end{tabular}

Source: Sample taken from SOEP 2007, own regressions (standard errors in parentheses); $* \mathrm{p}<0.1, * * \mathrm{p}<0.05, * * * \mathrm{p}<0.01$. 
Table 3: Compensating wage differences from social interaction in the job

\begin{tabular}{lcccc}
\hline \hline & $(1)$ pooled & $(2)$ pooled & $(3)$ males & (4) females \\
\hline schooling & $0.086^{* * *}$ & $0.085^{* * *}$ & $0.083^{* * *}$ & $0.086^{* * *}$ \\
& $(0.002)$ & $(0.002)$ & $(0.003)$ & $(0.003)$ \\
potexperience & $0.052^{* * *}$ & $0.052^{* * *}$ & $0.059^{* * *}$ & $0.048^{* * *}$ \\
& $(0.002)$ & $(0.002)$ & $(0.003)$ & $(0.003)$ \\
potexperience squared & $-0.001^{* * *}$ & $-0.001^{* * *}$ & $-0.001^{* * *}$ & $-0.001^{* * *}$ \\
& $(0.000)$ & $(0.000)$ & $(0.000)$ & $(0.000)$ \\
social interaction & $-0.041^{* * *}$ & -0.010 & -0.009 & $-0.072^{* * *}$ \\
& $(0.011)$ & $(0.016)$ & $(0.016)$ & $(0.016)$ \\
female & $-0.214^{* * *}$ & $-0.187^{* * *}$ & & \\
social interaction*female & $(0.011)$ & $(0.015)$ & & \\
& & $-0.061^{* * *}$ & & \\
constant & & $(0.022)$ & & \\
prob>F & $0.882^{* * *}$ & $0.879^{* * *}$ & $0.801^{* * *}$ & $0.773^{* * *}$ \\
Adj. $\mathrm{R}^{2}$ & $(0.033)$ & $(0.033)$ & $(0.044)$ & $(0.050)$ \\
$\mathrm{N}$ & 0.00 & 0.00 & 0.00 & 0.00 \\
\hline \hline
\end{tabular}

Source: Sample taken from SOEP 2007, OLS regressions (standard errors in parentheses), dependent variable: $\ln \left(\right.$ hwage); ${ }^{*} \mathrm{p}<0.1,{ }^{* *} \mathrm{p}<0.05,{ }^{* * *} \mathrm{p}<0.01$. 
Table 4: Further results on personality and wages

\begin{tabular}{lcc}
\hline \hline & $(1)$ males & $(2)$ females \\
\hline schooling & $0.083^{* * *}$ & $0.086^{* * *}$ \\
potexperience & $(0.003)$ & $(0.003)$ \\
potexperience squared & $0.059^{* * *}$ & $0.047^{* * *}$ \\
& $(0.003)$ & $(0.003)$ \\
social interaction & $-0.001^{* * *}$ & $-0.001^{* * *}$ \\
& $(0.000)$ & $(0.000)$ \\
extraversion*no social interaction & -0.004 & $-0.071^{* * *}$ \\
& $(0.016)$ & $(0.016)$ \\
extraversion* social interaction & 0.004 & 0.015 \\
& $(0.009)$ & $(0.012)$ \\
agreeableness*no social interaction & 0.016 & 0.004 \\
& $(0.013)$ & $(0.010)$ \\
agreeableness* social interaction & $-0.032^{* * *}$ & $-0.041^{* * *}$ \\
& $(0.008)$ & $(0.013)$ \\
constant & -0.011 & -0.017 \\
prob>F & $(0.014)$ & $(0.011)$ \\
adj. R ${ }^{2}$ & $0.789^{* * *}$ & $0.776 * * *$ \\
$\mathrm{~N}$ & $(0.044)$ & $(0.050)$ \\
\hline \hline
\end{tabular}

Source: Sample taken from SOEP 2007, OLS regressions (standard errors in parentheses), dependent variable: $\ln$ (hwage); ${ }^{*} \mathrm{p}<0.1,{ }^{* *} \mathrm{p}<0.05,{ }^{* * *} \mathrm{p}<0.01$. 
Appendix 1: The share of social interaction and average wages in the job, by ISCO-88 and gender

\begin{tabular}{lcccccc}
\hline \hline & \multicolumn{3}{c}{ males } & \multicolumn{3}{c}{ females } \\
\hline & percent & \multicolumn{2}{c}{$w(s d$ in brackets) } & percent & $w$ (sd in brackets) \\
\hline ISCO-01 & 100 & 12.62 & $(2.98)$ &. &. &. \\
ISCO-11 & 71 & 22.75 & $(7.20)$ & 100 & 17.34 & $(3.10)$ \\
ISCO-12 & 73 & 22.76 & $(8.78)$ & 94 & 17.28 & $(7.55)$ \\
ISCO-13 & 89 & 17.91 & $(9.81)$ & 93 & 12.59 & $(7.36)$ \\
ISCO-21 & 0 & 21.62 & $(8.65)$ & 0 & 17.61 & $(6.94)$ \\
ISCO-22 & 85 & 27.17 & $(9.46)$ & 92 & 20.19 & $(9.81)$ \\
ISCO-23 & 100 & 21.56 & $(6.42)$ & 100 & 19.34 & $(6.75)$ \\
ISCO-24 & 47 & 21.77 & $(8.55)$ & 60 & 17.91 & $(8.10)$ \\
ISCO-31 & 1 & 19.10 & $(7.68)$ & 0 & 15.13 & $(5.49)$ \\
ISCO-32 & 75 & 16.40 & $(6.24)$ & 90 & 12.91 & $(4.78)$ \\
ISCO-33 & 100 & 16.70 & $(8.43)$ & 100 & 13.97 & $(3.68)$ \\
ISCO-34 & 53 & 17.56 & $(8.32)$ & 41 & 13.38 & $(5.43)$ \\
ISCO-41 & 0 & 16.46 & $(7.49)$ & 17 & 12.56 & $(5.38)$ \\
ISCO-42 & 89 & 15.22 & $(6.03)$ & 99 & 9.96 & $(3.59)$ \\
ISCO-51 & 100 & 11.12 & $(5.77)$ & 100 & 8.95 & $(4.44)$ \\
ISCO-52 & 100 & 11.57 & $(5.87)$ & 100 & 8.58 & $(2.99)$ \\
ISCO-61 & 0 & 10.48 & $(4.67)$ & 0 & 7.12 & $(3.37)$ \\
ISCO-71 & 0 & 12.19 & $(4.99)$ & 0 & 8.14 & $(3.20)$ \\
ISCO-72 & 0 & 13.37 & $(5.52)$ & 0 & 10.54 & $(4.54)$ \\
ISCO-73 & 0 & 13.59 & $(4.43)$ & 0 & 10.53 & $(4.03)$ \\
ISCO-74 & 0 & 10.79 & $(4.60)$ & 0 & 9.13 & $(3.98)$ \\
ISCO-81 & 0 & 15.51 & $(5.64)$ & 0 & 11.63 &. \\
ISCO-82 & 0 & 14.00 & $(5.23)$ & 0 & 9.85 & $(3.77)$ \\
ISCO-83 & 27 & 10.67 & $(4.22)$ & 73 & 8.22 & $(2.25)$ \\
ISCO-91 & 87 & 11.79 & $(5.00)$ & 94 & 8.59 & $(3.65)$ \\
ISCO-92 & 0 & 7.94 & $(2.38)$ & 0 & 7.36 & $(4.60)$ \\
ISCO-93 & 0 & 11.26 & $(4.07)$ & 0 & 8.49 & $(3.09)$ \\
ISCO-99 & 41 & 12.84 & $(7.31)$ & 29 & 10.71 & $(7.95)$ \\
\hline \hline
\end{tabular}

Source: Own calculation; sample taken from SOEP (see text); N=3,315 females, 3,985 males;

ISCO Major Groups: 0 Armed Forces, 1 Legislators, senior officials and managers, 2

Professionals, 3 Technicians and associate professionals, 4 Clerks, 5 Service workers and shop and market sales workers, 6 Skilled agricultural and fishery workers, 7 Craft and related trade workers, 8 Plant and machine operators and assemblers, 9 Elementary occupations; for further information on ISCO-88, see http://laborsta.ilo.org/applv8/data/isco88e.html. 
Appendix 2: Odds-Ratios for social interaction in a desired job in a youth sample

\begin{tabular}{lccccc}
\hline \hline & $(1)$ pooled & $(2)$ males & means & (3) females & means \\
\hline sex & $2.381^{* * *}$ & & & & \\
openness to experience & $(0.459)$ & & & & \\
& 1.007 & 1.021 & -0.06 & 0.925 & 0.10 \\
conscientiousness & $(0.106)$ & $(0.138)$ & $(0.99)$ & $(0.166)$ & $(0.99)$ \\
extraversion & 1.097 & 0.998 & -0.11 & $1.341^{*}$ & 0.14 \\
& $(0.108)$ & $(0.122)$ & $(0.99)$ & $(0.227)$ & $(0.99)$ \\
agreeableness & $1.917^{* * *}$ & $2.029 * * *$ & -0.07 & $1.876^{* * *}$ & 0.13 \\
& $(0.206)$ & $(0.280)$ & $(0.99)$ & $(0.344)$ & $(0.95)$ \\
neuroticism & $1.449 * * *$ & $1.380^{* * *}$ & -0.15 & $1.614 * * *$ & 0.15 \\
locus of control & $(0.141)$ & $(0.170)$ & $(1.02)$ & $(0.272)$ & $(0.97)$ \\
willingness to take risk & 1.002 & 0.981 & -0.19 & 1.002 & 0.19 \\
& $(0.100)$ & $(0.128)$ & $(0.94)$ & $(0.166)$ & $(1.03)$ \\
immigrant & $1.227 * *$ & 1.118 & -0.01 & $1.505 * *$ & -0.02 \\
& $(0.124)$ & $(0.139)$ & $(1.02)$ & $(0.278)$ & $(0.98)$ \\
& 0.957 & 0.945 & 6.19 & 0.956 & 5.84 \\
constant & $(0.047)$ & $(0.057)$ & $(2.07)$ & $(0.086)$ & $(1.96)$ \\
& 0.862 & $0.527 *$ & 0.18 & 2.287 & 0.21 \\
pseudo R ${ }^{2}$ & $(0.250)$ & $(0.195)$ & $(0.39)$ & $(1.324)$ & $(0.41)$ \\
N & 1.865 & $8.594^{* * *}$ & & 4.149 & \\
\hline \hline
\end{tabular}

Source: Sample taken from SOEP 2007, Youth Questionnaires; Logistic regressions (standard errors in parentheses). Variables included in the regression, but not documented in the Table are: dummy for East-German origin, educational background of parents, dummy variable indicating that the individual lived with both parents until he/she was fifteen (the coefficients for these variables do not significantly differ from zero); ${ }^{*} \mathrm{p}<0.1$, ** $\mathrm{p}<0.05$, $* * * \mathrm{p}<0.01$. 